Cite this: Dalton Trans., 2014, 43, 290

Received 26th July 2013,

Accepted 19th September 2013

DOI: $10.1039 / c 3 d t 52037 d$

www.rsc.org/dalton

\title{
Synthesis and characterisation of ruthenium dihydrogen complexes and their reactivity towards $\mathrm{B}-\mathrm{H}$ bonds $\uparrow$
}

\author{
Jong-Hoo Choi, ${ }^{a}$ Nils E. Schloerer, ${ }^{a}$ Josefine Berger ${ }^{b}$ and Martin H. G. Prechtl ${ }^{{ }^{a}}$ \\ In this paper the synthesis and characterisation of ruthenium dihydrogen complexes bearing rigid \\ aliphatic PNP pincer-type ligands are described. As one result hydride complexes were synthesised in \\ good to high yields by a one-pot direct hydrogenation reaction. As another finding the dihydrogen \\ complex, stabilised with a N-Me group in the ligand frame, can be converted with dimethylamine borane \\ into a rare $\sigma$-boron complex $\left[\mathrm{RuH}_{2}\left(\mathrm{BH}_{3}\right)(\mathrm{Me}-\mathrm{PNP})\right]$ with rapid $\mathrm{B}-\mathrm{N}$ decoupling. Additionally, we present \\ the first mass spectrometric analysis of the synthesised $\sigma$-complexes via liquid injection field desorption/ \\ ionisation technique (LIFDI-MS).
}

\section{Introduction}

The development of transition metal complexes is still a field of increasing interest for application in homogeneous catalysis such as hydrogenation, ${ }^{1}$ dehydrogenation, ${ }^{2} \mathrm{C}-\mathrm{H}$ bond ${ }^{3}$ or $\mathrm{B}-\mathrm{H}$ bond activation. ${ }^{4}$ Amongst the large and various number of transition metal complexes, only a small collection is assigned to hydride complexes as intermediates, much less molecular dihydrogen complexes even though Kubas et al. first detected the molecular dihydrogen complexes in the 1980s. This expanded the diversity of complex chemistry. ${ }^{5-7}$ Since then, several dihydrogen transition metal complexes have been reported. Molecular dihydrogen ligands are coordinated in a side-on arrangement to the metal centre as $\sigma$-complexes. This denotation is due to the interaction between the electron donating $\sigma$-orbital of the $\mathrm{H}_{2}$ bond and the empty d-orbital at the metal centre and by the backdonation of the metal's d-orbitals into the empty $\sigma^{*}$-orbital of the hydrogen molecule. This type of bonding is also considered nonclassical due to its 3 -centre-2-electron (3c-2e) bonding character. ${ }^{8,9}$ Besides molybdenum and tungsten, various ruthenium based molecular dihydrogen complexes were reported, e.g., Chaudret et al. focussed on ruthenium based molecular dihydrogen complexes, stabilised by bulky ligands such as $\mathrm{PCy}_{3}$ (complex 1,

${ }^{a}$ Department of Chemistry, University of Cologne, Greinstr. 6, 50939 Cologne, Germany. E-mail: martin.prechtl@uni-koeln.de; http://www.catalysislab.de; Fax: +49221470 1788; Tel: +492214701981

${ }^{b}$ Institute of Chemistry, Humboldt University at Berlin, Brook-Taylor-Straße 2, D-12489 Berlin, Germany

$\dagger$ Electronic supplementary information (ESI) available. CCDC 952413. For ESI and crystallographic data in CIF or other electronic format see DOI: $10.1039 / \mathrm{c} 3 \mathrm{dt} 52037 \mathrm{~d}$
Fig. 1). ${ }^{10-12}$ Moreover, the reactivity of molecular dihydrogen complexes towards boryl adducts, such as amine boranes, turned into a field of increasing research due to its potential in the development of hydrogen storage systems. In recent reports, Sabo-Etienne et al. showed the reactivity of dihydrogen complex 1 in the presence of amine boranes by rapid hydrogen evolution. As a consequence, the transformation of complex 1 into "true" bis $(\sigma-\mathrm{B}-\mathrm{H})$ complexes $2 \mathrm{a}-\mathbf{c}$ was reported. ${ }^{13,14}$ So far, only a small number of "true" $\sigma$-borane complexes have been isolated. $^{14,15}$

Ruthenium dihydrogen complexes can also be stabilised with pincer ligands, for example complex 3 which was reported by Leitner. Complex 3 is capable of H/D exchange, hydrogenation or dehydrogenation and borylation of terminal alkynes. ${ }^{3,16-18}$ Besides complex 3, Schneider et al. reported ruthenium hydride complexes with an aliphatic, rigid PNPpincer ligand, which have been applied for homogeneous reduction of molecular dinitrogen to ammonia. ${ }^{19}$ In their study, two polyhydride complexes ( 4 and 5 ) have been assigned

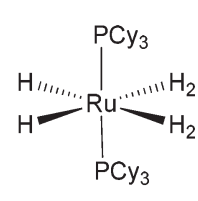

1

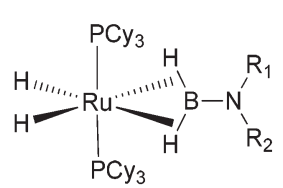

2a-c

$\mathrm{R}^{1}=\mathrm{R}^{2}=\mathrm{H} 2 \mathrm{a}$

$R^{1}=M e, R^{2}=H 2 b$

$R^{1}=R^{2}=M e 2 c$

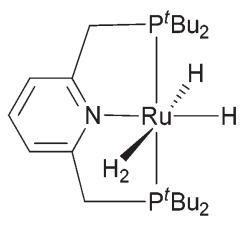

3
Fig. 1 Representative selection of ruthenium dihydrogen complexes and their bis $(\sigma-B-H)$ aminoborane complexes. 


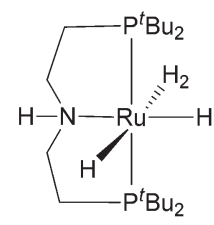

4

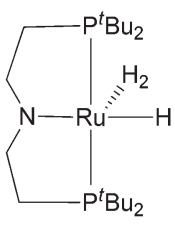

5

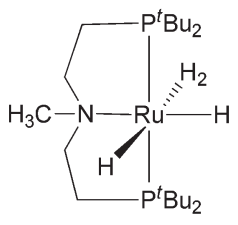

6
Fig. 2 Ruthenium dihydrogen complexes $\left[\mathrm{Ru}\left(\mathrm{H}_{2}\right) \mathrm{H}_{2}(\mathrm{HPNP})\right] 4$, $\left[\mathrm{Ru}\left(\mathrm{H}_{2}\right) \mathrm{H}\right.$ (PNP)] 5 and $\left[\mathrm{Ru}\left(\mathrm{H}_{2}\right) \mathrm{H}_{2}(\mathrm{Me}-\mathrm{PNP})\right] 6$.

as hydride complexes as intermediates (Fig. 2). However, the spectroscopic evidence provided by NMR relaxation time measurements was not convincing, since the presented data did not allow the extraction of a clearly defined $T_{1 \mathrm{~min}}$. The authors found for complex 4 a $T_{1 \mathrm{~min}}$ of $113 \mathrm{~ms}$ at $400 \mathrm{MHz}$, respectively $41 \mathrm{~ms}$ for complex 5 , and calculated $\mathrm{H}-\mathrm{H}$ distances of $1.57 \AA$ and $1.31 \AA$. Thus, they could be assumed with certain security as elongated dihydrogen complexes. Elongation of the hydrogen ligand in solution might have been affected by the coordinative character of the deuterated solvent THF. Therefore we used for $T_{1}$ measurements of the dihydrogen complexes deuterated toluene as a solvent. Herein we display the defined synthesis and characterisation of complexes $\mathbf{4}$ and $\mathbf{5}$ and the modified ruthenium hydride complex $\mathbf{6}$ bearing an aliphatic PNP ligand with a methylated nitrogen compound, following a typical synthetic protocol of ruthenium dihydrogen complexes. ${ }^{18}$ Moreover, we report the reactivity of complex 6 towards B-H bonds. For each complex, we present the first mass spectra of air and moisture sensitive small ruthenium dihydrogen complexes which allowed us a deeper insight into the compositions of our synthesised complexes.

\section{Results and discussion}

Synthesis and characterisation of ruthenium hydride 4 and 5

To synthesise the complexes 4 and 5, ruthenium precursor 7 and PNP ligand $\mathbf{8}$ were pressurised with hydrogen gas to obtain a product mixture in $90 \%$ yield, consisting of $43 \%$ of complex 4 and $57 \%$ of complex 5 (Scheme 1).

Starting with this product mixture, complex $\mathbf{5}$ was isolated but complex $\mathbf{4}$ appears to be stable only under a hydrogen atmosphere (see the Experimental section). Therefore, the product mixture was characterised by NMR and IR. The isolated complex $\mathbf{5}$ was analysed separately by IR and NMR, and the collected data were compared with the extracted data of the product mixture. The similarity of both hydride species 4 and 5 allows differentiation of the signals in the low field of ${ }^{31} \mathrm{P}$ and in the high field of ${ }^{1} \mathrm{H}$ NMR. Complex 4 shows a singlet at $111.9 \mathrm{ppm}$ in the ${ }^{31} \mathrm{P} \mathrm{NMR}$ and a triplet at -8.26 ppm $\left({ }^{2} J_{P H}=14.7 \mathrm{~Hz}\right)$ in the ${ }^{1} \mathrm{H}$ NMR spectrum, while the singlet in ${ }^{31} \mathrm{P}$ NMR for 5 appears at $114.3 \mathrm{ppm}$ and its triplet signal in the ${ }^{1} \mathrm{H}$ NMR spectrum at $-12.44 \mathrm{ppm}\left({ }^{2} J_{P H}=\right.$ 10.6 Hz). For assignment of the ruthenium complexes to elongated and nonclassical hydrides (4-5), we performed $T_{1}$

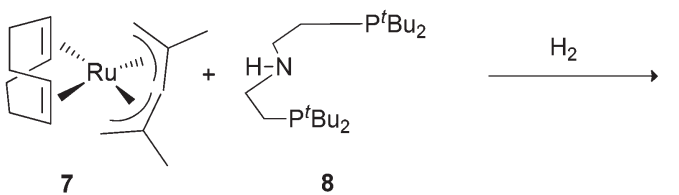

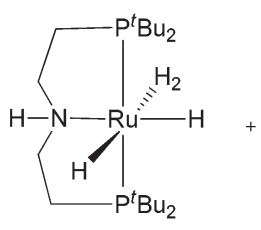

4

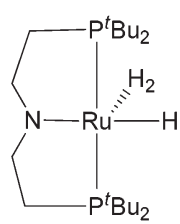

Scheme 1 Synthesis of ruthenium dihydrogen complexes 4 and 5 by one-pot direct hydrogenation.

relaxation time measurements of the complex mixture between $298 \mathrm{~K}$ and $193 \mathrm{~K}$ at $500 \mathrm{MHz}$ in deuterated toluene. $\left[\mathrm{Ru}\left(\mathrm{H}_{2}\right)\right.$ $\left.\mathrm{H}_{2}(\mathrm{PNP})\right] 4$ passes through a substance specific minimum $\left(\Theta_{\min }\right)$ at $223 \mathrm{~K}$ with a $T_{1 \mathrm{~min}}$ value of $132 \mathrm{~ms}$ at $500 \mathrm{MHz}$ (ESI, Fig. S1 $\dagger$ ). For $\left[\mathrm{Ru}\left(\mathrm{H}_{2}\right) \mathrm{H}(\mathrm{HPNP})\right] 5$, the $T_{1 \mathrm{~min}}$ value of $48 \mathrm{~ms}$ was matched at $207 \mathrm{~K}$ (ESI, Fig. S2 $\dagger$ ). The $\mathrm{H}-\mathrm{H}$ distance $d_{\mathrm{HH}}$ for complex 4 has a calculated value of $1.17 \AA$ and is assigned to the range of an elongated dihydrogen complex (1.1-1.36 $\AA$ ) defined by Kubas. ${ }^{12}$ In contrast to complex 4, the trihydride [Ru$\left.\left(\mathrm{H}_{2}\right) \mathrm{H}(\mathrm{PNP})\right] 5$ is assigned to a nonclassical dihydrogen complex $(0.8-1.0 \AA),{ }^{12}$ with a calculated $\mathrm{H}-\mathrm{H}$ bond length of $0.99 \AA$.

The IR spectra of both complexes show $\nu(\mathrm{M}-\mathrm{H})$ bands (ESI, Fig. S5 $\dagger$ ) between 2034 and $2000 \mathrm{~cm}^{-1}$ in a typical range of $\mathrm{Ru}-\mathrm{H}$ bonding. ${ }^{20,21}$ For characteristic $\nu\left(\mathrm{M}-\mathrm{H}_{2}\right)$ vibration, complex 4 shows a significant $\mathrm{Ru}-\mathrm{H}_{2}$ band at $1726 \mathrm{~cm}^{-1}$. $^{7}$ Complex 5, probably due to its pyramidal arrangement and amide-type ligand, seems to have a shorter $\mathrm{N}-\mathrm{Ru}$ bond length, an elongated $\mathrm{Ru}-\mathrm{H}_{2}$ distance and a shifted $\mathrm{Ru}-\mathrm{H}_{2}$ band at $1975 \mathrm{~cm}^{-1}$ as a shoulder of the bigger $\nu(\mathrm{M}-\mathrm{H})$ band. The isotope pattern of complex 5 in the LIFDI-MS (Fig. 3) appears to be different from its simulated isotope pattern (ESI, Fig. S12 $\dagger$ ). This can be explained by the additional overlaps of

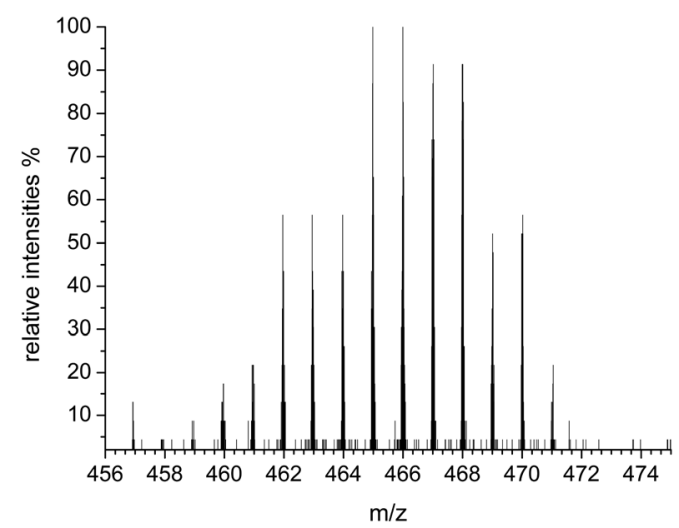

Fig. 3 LIFDI-MS analysis of $\left[\mathrm{Ru}\left(\mathrm{H}_{2}\right) \mathrm{H}(\mathrm{PNP})\right] 5$ in toluene. Isotope pattern areas: [RuH(PNP)] 457-466, $\left[\mathrm{RuH}_{2}(\mathrm{PNP})\right]$ 458-467 and $\left[\mathrm{Ru}\left(\mathrm{H}_{2}\right) \mathrm{H}(\mathrm{PNP})\right]$ 459-468, $\left[\mathrm{Ru}\left(\mathrm{H}_{2}\right) \mathrm{H}_{2}(\mathrm{HPNP})\right]$ 461-470. 
isotope patterns of co-existent $\left[\mathrm{Ru}\left(\mathrm{H}_{2}\right) \mathrm{H}_{2}(\mathrm{HPNP})\right]$, [ $\left.\mathrm{RuH}_{2}(\mathrm{PNP})\right]$ and $[\mathrm{RuH}(\mathrm{PNP})]$ species with the $\mathrm{m} / \mathrm{z}$ isotope pattern of $\left[\mathrm{Ru}\left(\mathrm{H}_{2}\right) \mathrm{H}(\mathrm{PNP})\right]$ generated during the ionisation and analysis process under MS-conditions. Moreover, under MS conditions, we observed the formation of a decomposition product with a mass 101 units higher than complex 5 which can be tentatively assigned to a complex coordinating two $\mathrm{Ru}$ cores. The same observation has been made with other ruthenium complex under MS conditions. In consequence, summated intensities of ruthenium isotopes of different complexes are observed in the LIFDI-MS, shifting the $\mathrm{m} / \mathrm{z}$ values of the collective pattern up to $\Delta 2$. However, the exact quantitative ratio of the existent ruthenium species could not be defined, but it can be reported that ruthenium hydride subspecies are coexistent in small amounts.

\section{Equilibrium of ruthenium hydride 4 and 5}

We assume that the lability of tetrahydride $\mathbf{4}$ can be explained by the cooperative properties of the H-PNP pincer backbone. The $\mathrm{N}-\mathrm{H}$ ligand module can be deprotonated to complex $\mathbf{5}$. The nitrogen building block serves as a proton donor and an acceptor similar to the benzylic position in pyridine based PNN or PNP pincer complexes. ${ }^{1,22,23}$ Therefore, shifting the equilibrium towards the more stable complex 5 by removing one equivalent of $\mathrm{H}_{2}$ was facile (Scheme 2), while the isolation of pure complex 4 was not possible under an argon atmosphere. Complex 5 in the presence of isopropanol as a hydrogen source in a closed system at $80{ }^{\circ} \mathrm{C}$ for $20 \mathrm{~h}$ emulates complex 4 until the equilibrium between the tetra- and trihydride complexes is restored. This process was monitored via ${ }^{1} \mathrm{H}$ and ${ }^{31} \mathrm{P}$ NMR in deuterated benzene. Additionally, we achieved the full regeneration of complex $\mathbf{4}$ by treatment of complex 5 dissolved in deuterated toluene with 2 bar of hydrogen gas; the NMR showed the exclusive presence of tetrahydride $\mathbf{4}$, which is stable only under a hydrogen atmosphere.

\section{Synthesis and characterisation of $\left[\mathrm{Ru}\left(\mathrm{H}_{2}\right) \mathrm{H}_{2}(\mathrm{Me}-\mathrm{PNP})\right] 6$}

Complex 6 was obtained by following the synthetic route of complexes 4 and 5 (Scheme 3). Contrary to ligand 8, ligand 9
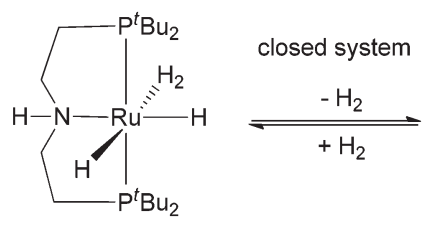

4

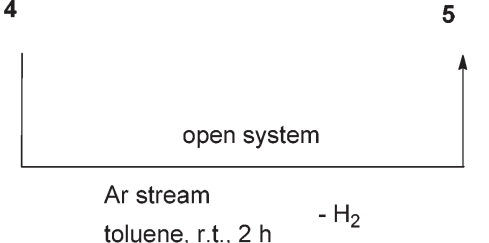

Scheme 2 Equilibrium between ruthenium dihydrogen complexes 4 and $\mathbf{5}$ in the presence of isopropanol as a hydrogen source in a closed system monitored via ${ }^{1} \mathrm{H}$ - and ${ }^{31} \mathrm{P}-\mathrm{NMR}$. Complex 5 is isolated through a constant stream of argon.

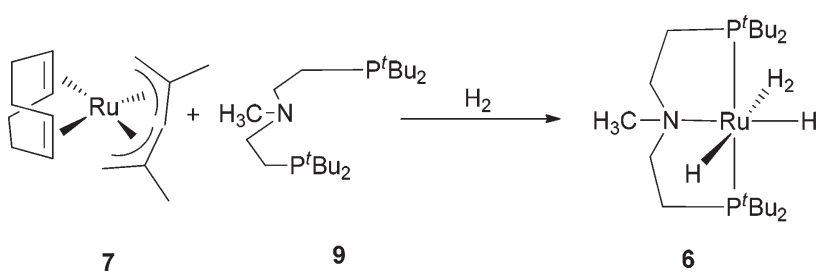

Scheme 3 Synthesis of ruthenium dihydrogen complexes 6 by one-pot direct hydrogenation.

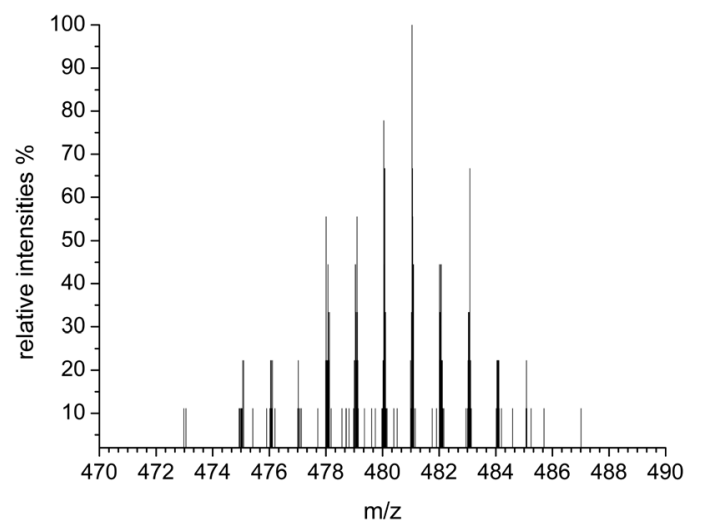

Fig. 4 LIFDI-MS analysis of $\left[\mathrm{Ru}\left(\mathrm{H}_{2}\right) \mathrm{H}_{2}(\mathrm{Me}-\mathrm{PNP})\right] 6$ in toluene. Isotope pattern areas: [RuH $\left.{ }_{2}(\mathrm{Me}-\mathrm{PNP})\right]$ 473-482, [Ru( $\left.\left.\mathrm{H}_{2}\right) \mathrm{H}(\mathrm{Me}-\mathrm{PNP})\right]$ 474-485 and $\left[\mathrm{Ru}\left(\mathrm{H}_{2}\right) \mathrm{H}_{2}(\mathrm{Me}-\mathrm{PNP})\right]$ 475-484.

contains a methyl group blocking the nitrogen position. Therefore, cooperative properties acting as a proton donor or an acceptor are avoided, thus a conversion of the tetrahydride into a trihydride is not possible due to the absence of a neighbouring proton source. The synthesis of complex 6 provides yields between 64 and $67 \%$ as a powderous grey solid.

At room temperature, complex 6 shows a singlet signal at 108.7 ppm in the ${ }^{31} \mathrm{P}$ NMR spectrum as well as a characteristic triplet signal at $-8.68 \mathrm{ppm}\left({ }^{2} J_{P H}=13.8 \mathrm{~Hz}\right)$ in the ${ }^{1} \mathrm{H}$ NMR spectrum, allocating two hydride ligands and one dihydrogen ligand coordinated to ruthenium. The $T_{1}$ measurement of complex 6 resulted in a $T_{1 \mathrm{~min}}$ value of $54 \mathrm{~ms}$ at $224 \mathrm{~K}$ in deuterated toluene with a spectrometer frequency of $500 \mathrm{MHz}$. The $\mathrm{H}-\mathrm{H}$ bond length of $1.01 \AA$ was calculated, which assigns complex 6 to a nonclassical dihydrogen complex (ESI, Fig. $\mathrm{S} 4 \dagger)$. The IR spectrum of $\left[\mathrm{Ru}\left(\mathrm{H}_{2}\right) \mathrm{H}_{2}(\mathrm{Me}-\mathrm{PNP})\right] 6$ indicates the dihydrogen ligand vibration $\nu(\mathrm{M}-\mathrm{H})$ between 1972 and $1923 \mathrm{~cm}^{-1}$ (ESI, Fig. S6 $\dagger$ ), and the vibration of the hydrides $\nu\left(\mathrm{M}-\mathrm{H}_{2}\right)$ at $1776 \mathrm{~cm}^{-1}$, similar to complex 4 with an analogue octahedral complex arrangement. Compared to the LIFDI-MS isotope pattern of complex 5, the LIFDI-MS isotope pattern of complex 6 shows a relatively neat isotope pattern of ruthenium species $\left[\mathrm{Ru}\left(\mathrm{H}_{2}\right) \mathrm{H}_{2}\right.$ (Me-PNP)] (Fig. 4) and is in good agreement with its simulated isotope pattern (ESI, Fig. S17†).

\section{Reactivity of $\left[\mathrm{Ru}\left(\mathrm{H}_{2}\right) \mathrm{H}_{2}(\mathrm{Me}-\mathrm{PNP})\right] 6$ towards $\mathrm{B}-\mathrm{H}$ bonds}

$\left[\mathrm{Ru}\left(\mathrm{H}_{2}\right) \mathrm{H}_{2}(\mathrm{Me}-\mathrm{PNP})\right] 6$ reacts sensitively to $\mathrm{B}-\mathrm{H}$ bonds with rapid hydrogen evolution. In this work we particularly 

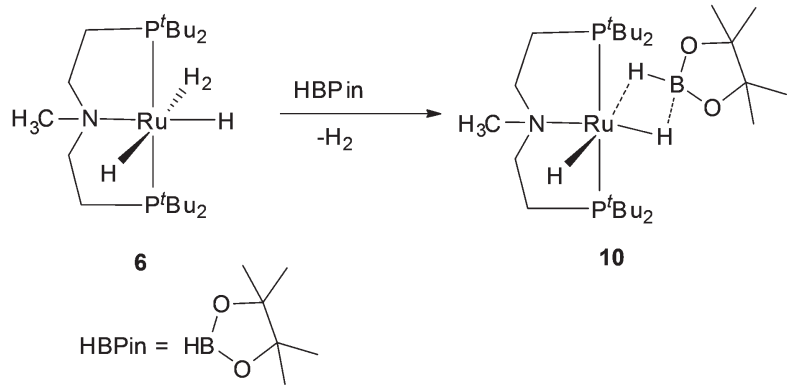

Scheme 4 Reaction of 6 with pinacolborane to complex 10 with evolution of hydrogen gas.

identified the reaction with pinacolborane and dimethylamine borane leading to ruthenium boryl complexes $\mathbf{1 0}$ and $\mathbf{1 1 .}$

\section{Synthesis and characterisation of $\left[\mathrm{RuH}_{2}(\mathrm{HBPin})(\mathrm{Me}-\mathrm{PNP})\right] 10$}

$\left[\mathrm{RuH}_{2}(\mathrm{HBPin})(\mathrm{Me}-\mathrm{PNP})\right] \mathbf{1 0}$ was obtained in toluene with 1.0-1.1 equivalents of pinacolborane under rapid hydrogen evolution as a solid in $88 \%$ yield after removing the solvent (Scheme 4). The IR spectrum of complex 10 shows the $\nu(\mathrm{M}-\mathrm{H})$ band at $2024 \mathrm{~cm}^{-1}$ and the two bridging hydride bands $\nu(\mathrm{M}-\mathrm{H}-\mathrm{B})$ between 1973 and $1914 \mathrm{~cm}^{-1}$ and between 1744 and $1675 \mathrm{~cm}^{-1}$ (ESI, Fig. S7 ). In deuterated cyclohexane, the characteristic signals appear in the highfield region of ${ }^{1} \mathrm{H}$ NMR at $-5.64,-9.02$ and -18.85 ppm as broad singlets assigned to the bridging hydrides and the $\mathrm{Ru}-\mathrm{H}$ hydride. In contrast to complex 10, the comparable borylated PNP complex with a pyridine backbone obtained by the ruthenium dihydrogen complex 3 contains only one singlet signal for the bridging hydrides in the ${ }^{1} \mathrm{H}$ NMR spectrum, which is presumably caused by the electronic effect of the ligand and the generally vibrant system of the complex. ${ }^{17}$ In fact, only one signal was detected in the ${ }^{31} \mathrm{P}$ NMR spectrum at $92.1 \mathrm{ppm}$, which excludes the assumption of a second similar complex.

LIFDI-MS analysis confirmed structure $10(\mathrm{~m} / \mathrm{z}$ 602-610, Fig. 5). Furthermore, fragments of $\left[\mathrm{RuH}_{2}(\mathrm{Me}-\mathrm{PNP})\right]$ and $\left[\mathrm{RuH}_{3}(\mathrm{Me}-\mathrm{PNP})\right]$ were detected in the MS. The approaching simulated isotope pattern of $\left[\mathrm{RuH}_{3}(\mathrm{Me}-\mathrm{PNP})\right]$ (red) is in good agreement with the analysed fragment (black) which consists mainly of the $\left[\mathrm{RuH}_{3}(\mathrm{Me}-\mathrm{PNP})\right]$ species.

\section{Synthesis and characterisation of $(\sigma-\mathrm{B}-\mathrm{H})$ complex $\left[\mathrm{RuH}_{2}\left(\mathrm{BH}_{3}\right)(\mathrm{Me}-\mathrm{PNP})\right] 11$}

$\left[\mathrm{RuH}_{2}\left(\mathrm{BH}_{3}\right)(\mathrm{Me}-\mathrm{PNP})\right] 11$ was obtained with different synthetic routes (a-b, Scheme 5). The reaction of dihydrogen complex 6 with 2-3 equivalents of the THF borane complex ( $1 \mathrm{M}$ in THF) in a mixture of toluene and pentane resulted in rapid hydrogen evolution. Although high yields (89\%) and high conversions ( $>95 \%)$ were obtained THF traces were still visible in the ${ }^{1} \mathrm{H}$ NMR. More interestingly, the synthetic route $\mathbf{b}$ adding 3-5 equivalents of dimethylamine borane led to the decoupling of the $\mathrm{N}-\mathrm{B}$ bond with the formation of the $(\sigma-\mathrm{B}-\mathrm{H})$-ruthenium complex 11 and loss of the dimethylamine in 91\% yields. This reactivity stays in contrast to previous reports by Sabo-Etienne

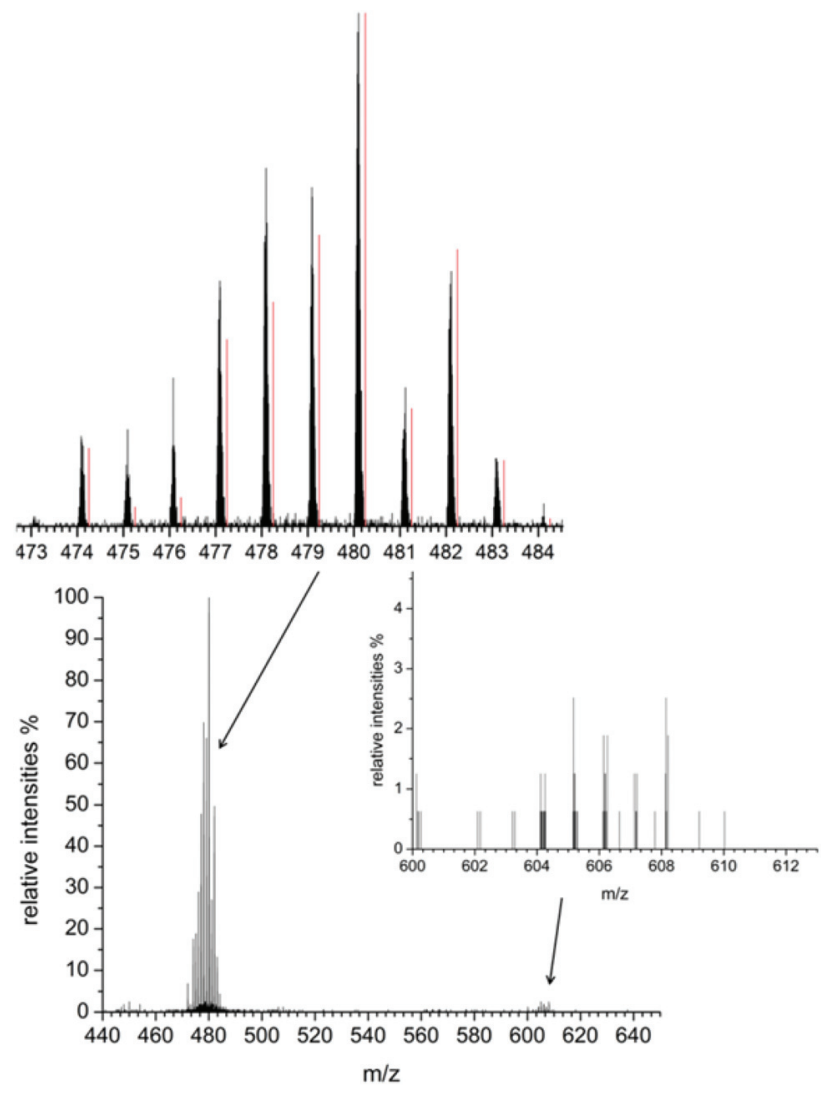

Fig. 5 LIFDI-MS analysis of $\left[\mathrm{RuH}_{2}(\mathrm{HBPin})(\mathrm{Me}-\mathrm{PNP})\right] 10$ in toluene. Isotope pattern areas: [RuH $\left.\mathrm{H}_{2}(\mathrm{HBPin})(\mathrm{Me}-\mathrm{PNP})\right]$ 602-610. $\left[\mathrm{RuH}_{2}(\mathrm{Me}-\right.$ PNP)] 473-482 (black), [Ru( $\left.\left.\mathrm{H}_{2}\right) \mathrm{H}(\mathrm{Me}-\mathrm{PNP})\right]$ 474-484 (black) in comparison to the simulated isotope pattern of fragment $\left[\mathrm{RuH}_{3}(\mathrm{Me}-\mathrm{PNP})\right]$ 474-484 (red).

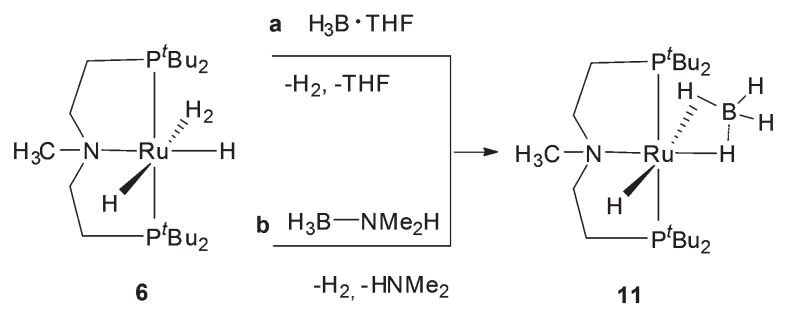

Reaction of dihydrogen complex 1 with amine bor ane:<smiles>CCCCC(C)(C)C</smiles>

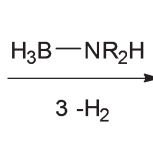

$-\mathrm{H}_{2}$

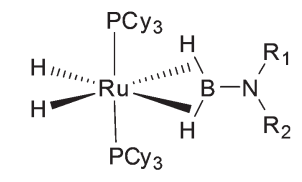

2a-c

$$
\begin{aligned}
& R^{1}=R^{2}=H 2 a \\
& R^{1}=M e, R^{2}=H 2 b \\
& R^{1}=R^{2}=\text { Me 2c }
\end{aligned}
$$

Scheme 5 Reaction of 6 to complex 11 with evolution of hydrogen gas. Synthetic route a with THF borane complex, synthetic route $b$ with dimethylamine borane in comparison to complex 1 with amine boranes leading to complex $2 \mathrm{a}-\mathrm{c}$. $^{13}$ 


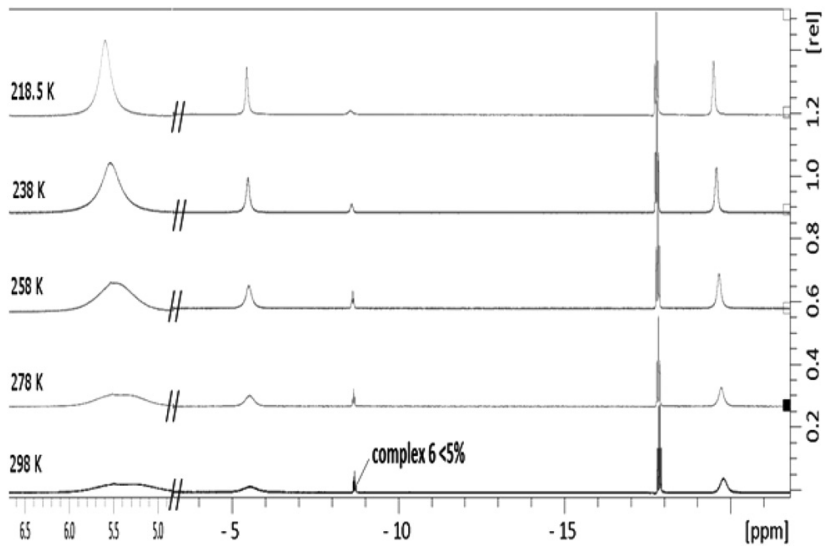

Fig. $6{ }^{1} \mathrm{H}$ NMR signals $\left(\mathrm{Ru}-\mathrm{H}, \mathrm{BH}_{3}\right)$ of $\left[\mathrm{RuH}_{2}\left(\mathrm{BH}_{3}\right)\right] 11$ at various temperatures between 218.5 and $298 \mathrm{~K}$ in deuterated toluene $(400 \mathrm{MHz})$.

where the dihydrogen complex $\left[\mathrm{Ru}\left(\mathrm{PCy}_{3}\right)_{2}\left(\mathrm{H}_{2}\right)\left(\mathrm{H}_{2}\right)_{2}\right] 1$ reacts with amine boranes under dehydrogenation to bis- $\sigma$-borane complexes 2a-c (Scheme 5). In their observation, two dihydrogen $\sigma$-ligands were substituted by the borane with formations of $\sigma-\mathrm{B}-\mathrm{H}$ bonds and simultaneously the B-N adducts were connected. This observation might be related to slightly different electronic properties of the ruthenium core in $\left[\mathrm{Ru}\left(\mathrm{PCy}_{3}\right)_{2}\left(\mathrm{H}_{2}\right)-\right.$ $\left.\left(\mathrm{H}_{2}\right)_{2}\right] 1$ compared to $\left[\mathrm{Ru}\left(\mathrm{H}_{2}\right) \mathrm{H}_{2}(\mathrm{Me}-\mathrm{PNP})\right] \mathbf{6}$, which could be explained by the different ligand types (monodentate ligands vs. pincer ligand).

The ${ }^{31} \mathrm{P}$ NMR spectrum of complex 11 shows a singlet signal at $84.9 \mathrm{ppm}$. At room temperature, the characteristic signals in the ${ }^{1} \mathrm{H}$ NMR appear at $5.42 \mathrm{ppm}$ as a broad singlet signal, attributed to the terminal hydrogen atoms of boron. The broad singlet signals at -5.69 and $-19.76 \mathrm{ppm}$ are assigned to the bridging hydrides. The remaining hydride signal appears at $-17.85 \mathrm{ppm}$ as a triplet of doublets. At lower temperatures, the broad signals were sharpened and the triplet of doublets at $-\mathbf{1 7 . 8 5} \mathrm{ppm}$ was adjusted into a clear triplet (Fig. 6). Also integral assignments of the hydrogen atoms in the ${ }^{1} \mathrm{H}$ NMR spectrum were more accurate at temperatures below $278 \mathrm{~K}$.

The IR spectrum of complex 11 obtained with route a contains traces of THF, but is congruent with the complex $\mathbf{1 1}$ obtained with route b (Fig. 7). Two strong bands appear at 2394 and $2330 \mathrm{~cm}^{-1}$ in a typical range of terminal B-H region. ${ }^{4,15,24-26}$ The $\nu(\mathrm{M}-\mathrm{H})$ was found at $2020 \mathrm{~cm}^{-1}$ and is in accordance with previous reports. ${ }^{4,20,21,26}$ The band at $1693 \mathrm{~cm}^{-1}$ can be carefully assigned to $\nu(\mathrm{Ru}-\mathrm{H}-\mathrm{B}) .{ }^{15}$ No characteristic $\mathrm{N}-\mathrm{Me}$ or $\mathrm{N}-\mathrm{H}$ band of the amine borane adduct was found either in the ${ }^{1} \mathrm{H}$ or ${ }^{13} \mathrm{C}$ NMR spectra or in the IR spectrum in the region of $3000 \mathrm{~cm}^{-1}$ or higher. This profoundly indicates that no ruthenium dimethylaminoborane complex has been generated with route $\mathbf{b}$, but a $\sigma-\mathrm{B}-\mathrm{H}$ typed $\mathrm{BH}_{3}$ ruthenium complex instead.

The single crystal X-ray analysis of the structure was determined at $293 \mathrm{~K}$ (Fig. 8, Table 1). Further refinement parameters and collected data are listed in the ESI. $\dagger$ The hydrogen atoms $(\mathrm{H} 1-\mathrm{H} 5)$ were approached by electron densities around

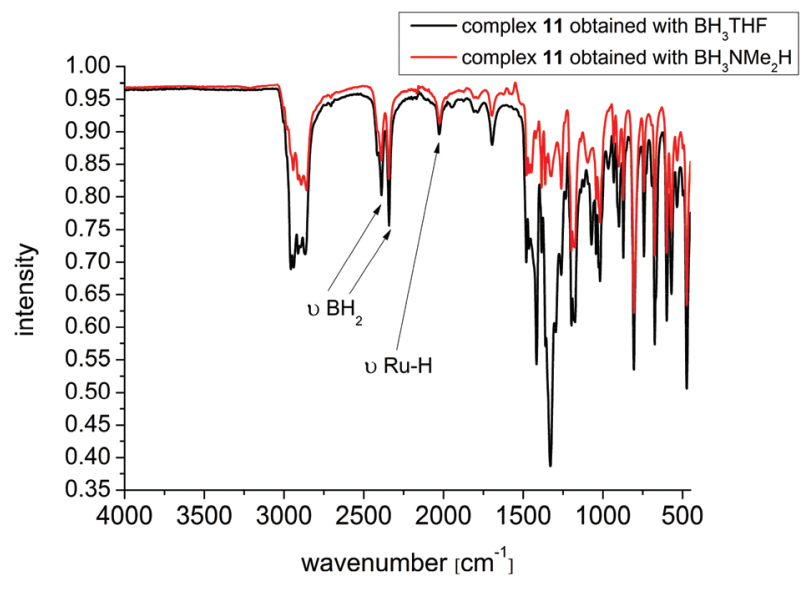

Fig. 7 IR spectra of complex 11 . Vibrational bands are identical beside the THF traces independent from the different synthetic routes with $\mathrm{BH}_{3} \mathrm{THF}$ (black) or $\mathrm{BH}_{3} \mathrm{NMe}_{2} \mathrm{H}$ (red).

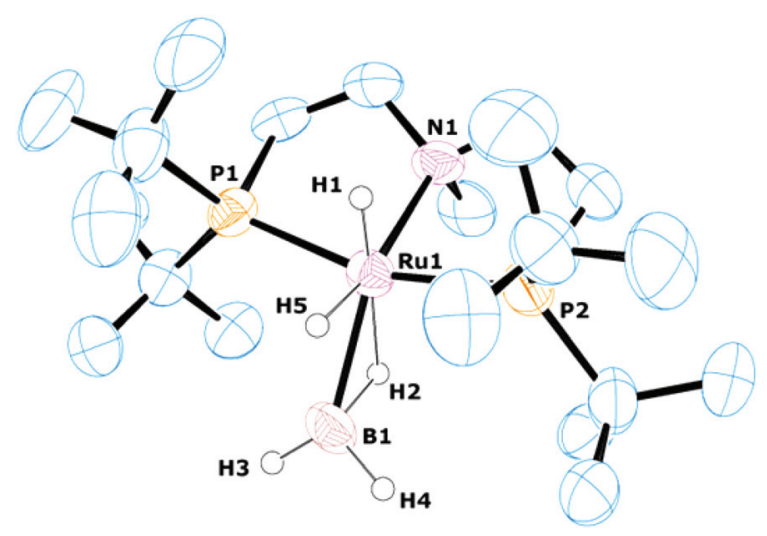

Fig. 8 ORTEP diagram of the single crystal structure of complex 11. Ellipsoids are illustrated at $50 \%$ possibility. All hydrogen atoms are faded out except for $\mathrm{H} 1-\mathrm{H} 5$ for clarity.

Table 1 Selected bond distances ${ }^{a}$ and angles ${ }^{b}$ of complex 11

\begin{tabular}{lllr}
\hline Ru1-P1 & $2.32(7)$ & P1-Ru1-P2 & 163.06 \\
Ru1-P2 & $2.33(3)$ & Ru1-H2-B1 & 92.76 \\
Ru1-N1 & $2.18(9)$ & H1-Ru1-H2 & 170.78 \\
Ru1-H1 & $1.36(6)$ & H1-Ru1-P1 & 63.28 \\
Ru1-H5 & $1.48(8)$ & H1-Ru1-P2 & 65.96 \\
Ru1-H2 & $1.69(2)$ & N1-Ru1-B1 & 143.08 \\
Ru1-B1 & $2.19(2)$ & H3-B1-H4 & 108.16 \\
B1-H2 & $1.31(6)$ & & \\
B1-H5 & $1.84(2)$ & & \\
B1-H3 & $1.04(6)$ & & \\
B1-H4 & $1.15(7)$ & &
\end{tabular}

${ }^{a}$ Distances are given in $\AA .{ }^{b}$ Angles are reported in degrees.

the ruthenium and boron atoms. Thus we located the most likely electron density for $\mathrm{H} 1$ which contains a short distanced Ru1-H1 bond length of slightly under $<1.4 \AA$ A . Despite the imprecise short bond length of Ru1-H1, the location of $\mathrm{H} 1$ confirms only the trans arrangement of the hydride. Furthermore the Ru-B distance is 2.19(2) $\AA$ and thus in the range of previously reported agostic ruthenium boron complexes. ${ }^{13,14}$ 
The bridging hydrogen atom $(\mathrm{H} 2)$, which replaced the position of the molecular hydrogen ligand of complex 6, is located $1.69(2) \AA$ next to the ruthenium atom and 1.31(6) $\AA$ to the boron atom with an angle (degree) of 92.76 for Ru1-H2-B1 on the trans axial position to the terminal hydride (H1). This arrangement is in agreement with a typical "true" $(\sigma-\mathrm{B}-\mathrm{H})$ bonding to ruthenium reported by Sabo-Etienne et al. ${ }^{13,14}$ Moreover, $\mathrm{H} 1$ can be attributed as a hydride, although the short Ru1-H5 distance of 1.48(8) $\AA$ is rarely known in the literature, but throughout transition metal-hydride distances of $\mathrm{Ni}-\mathrm{H}, \mathrm{Fe}-\mathrm{H}, \mathrm{Pt}-\mathrm{H}$ or $\mathrm{Ru}-\mathrm{H}$ around $1.5 \AA$ or $<1.5 \AA$ have been already reported by others. ${ }^{27-31}$ More interestingly the B1-H5 distance remains too stretched with 1.84(2) A for a fixed B-H bonding mode. This fact encouraged us to assume the coordinated boron as a $\sigma-\mathrm{BH}_{3}$ adduct instead of the originally considered $\eta^{2}$-type $\mathrm{BH}_{4}{ }^{-}$adduct with expected symmetric arrangement for both hydrides $\mathrm{H} 2$ and $\mathrm{H} 5$ with distances of 1.67-1.85 ̊ to ruthenium and 1.25-1.3 ̊ to boron, such as the PNP ruthenium $\eta^{2}-\mathrm{BH}_{4}{ }^{-}$complex spotted by Milstein. ${ }^{24}$ In our case, the rare type of $\sigma$-boron complex $\mathbf{1 1}$ is most comparable with the $\left[\mathrm{IrH}_{2}\left(\mathrm{BH}_{3}\right)(\mathrm{POCOP})\right]$ complex presented by Goldberg and Heinekey. ${ }^{15}$ Despite the different transition metal, they reported a similar arrangement of the boron and hydrides to the iridium centre. The $\left[\mathrm{IrH}_{2}\left(\mathrm{BH}_{3}\right)(\mathrm{POCOP})\right]$ complex also contains a bridging hydride in a $\sigma-\mathrm{B}-\mathrm{H}$ fashion with a distance to ruthenium of around $1.90 \AA$ and to boron of around $1.45 \AA$. The opposite $\mathrm{Ru}-\mathrm{H}-\mathrm{B}$ bonding distance of $1.74 \AA(\mathrm{Ru}-\mathrm{H}$ and $\mathrm{H}-\mathrm{B}$ ) is too stretched to be considered as a $\mathrm{BH}_{4}{ }^{-}$rather than a $\mathrm{BH}_{3}$ adduct. All together, the similarity of $\left[\mathrm{IrH}_{2}\left(\mathrm{BH}_{3}\right)(\mathrm{POCOP})\right]$ to complex $\mathbf{1 1}$ clearly argues against the assumption of a $\eta^{2}-\mathrm{BH}_{4}{ }^{-}$adduct, but emphasises the existence of a $\sigma$-borane complex.

Moreover the solid state structure of $\mathbf{1 1}$ confirms the bond cleavage of the dimethylamine borane. The reactivity of complex 6 towards THF borane complex or dimethylamine borane, in routes $\mathbf{a}$ and $\mathbf{b}$, remains still uncleared, but regarding the borane compounds as Lewis-pairs, it is plausible that THF or dimethylamine is replaced by a stronger Lewis base system (Fig. 9). In this case, the methyl group of the PNP backbone of complex 6 could electronically influence the ruthenium metal centre by inducing Lewis-base character into the system. This consideration would explain the possibility of a Lewis-pair exchange during the synthesis of complex 11.

Furthermore, the basic character of complex 11 could tend to draw the more "protic" hydride H5 closer to the ruthenium centre, which would explain the short distance of Ru1-H5 of

$$
\begin{aligned}
& L_{A}-L_{B 1}+L_{B 2} \underset{\text { exchange }}{\longrightarrow} L_{A}-L_{B 2}+L_{B 1} \\
& L_{A}=B H_{3} \\
& L_{B 1}=T H F \text { or } \mathrm{HNMe}_{2} \\
& L_{B 2}=\text { complex } 6
\end{aligned}
$$

Fig. 9 Simplified Lewis pair exchange, THF or $\mathrm{HNMe}_{2}$ is replaced by a stronger Lewis base (complex 6).

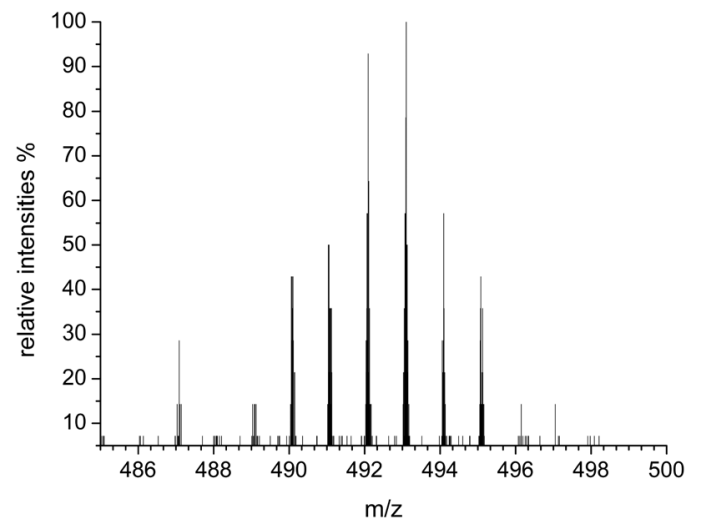

Fig. 10 LIFDI-MS analysis of $\left[\mathrm{RuH}_{2}\left(\mathrm{BH}_{3}\right)(\mathrm{Me}-\mathrm{PNP})\right] 11$ in toluene. Isotope pattern area: $\left[\mathrm{RuH}_{2}\left(\mathrm{BH}_{3}\right)(\mathrm{Me}-\mathrm{PNP})\right]$ 487-498.

1.48(8) Å. LIFDI-MS analysis of $\left[\mathrm{RuH}_{2}\left(\mathrm{BH}_{3}\right)(\mathrm{Me}-\mathrm{PNP})\right] 11$ confirms additionally the assumed structure (Fig. 10) and is in agreement with the simulated isotope pattern (ESI, Fig. S23†).

\section{Conclusion}

In summary, we demonstrated an efficient and simple synthesis of ruthenium dihydrogen complexes 4-6, stabilised with a rigid aliphatic PNP backbone. These complexes have been characterised via $T_{1}$ spin lattice measurement as molecular dihydrogen complexes (5 and $\mathbf{6}$ ) and as an elongated dihydrogen complex 4. The methylated pincer ligand of complex 6 shows the major influence on its electron density and proved to be highly active towards $\mathrm{B}-\mathrm{H}$ groups, emphasising the formation of complex $\mathbf{1 0}$ and the B-N decoupling of the dimethylamine borane to a rare $\sigma$-borane complex 11. All structures have been confirmed by LIDS-MS analysis, which allowed us a good insight into the complexes.

\section{Experimental section}

\section{General information}

Reactions were generally prepared under an argon atmosphere using Schlenk techniques, flame-dried glassware and a Labmaster 200 glove-box from Mbraun. High-pressure hydrogen reactions were performed in a Büchi Tinyclave $(50 \mathrm{~mL})$ glass autoclave. All solvents and reagents were purchased from Acros, Merck, Sigma-Aldrich, Fluka, Strem or were acquired from the institute stock. Commercial anhydrous solvents and argongas packed reagents were used as received and stored in the glove-box under an argon atmosphere. Non-anhydrous solvents were dried and distilled (under vacuum or argon) prior to use, applying standard procedures. The water content of solvents, alcohols and amines has been quantified by Karl-Fischer titration.

\section{Analytic methods}

${ }^{1} \mathrm{H},{ }^{13} \mathrm{C},{ }^{11} \mathrm{~B},{ }^{31} \mathrm{P}$ NMR spectra were recorded using a Bruker Avance II 300 spectrometer and a Bruker Avance II+ 600 
spectrometer using deuterated benzene, toluene, cyclohexane, THF and deuterium oxide as solvents at room temperature. ${ }^{1} \mathrm{H}$ NMR spectra measurements at various temperatures were recorded using a Bruker Avance 400 spectrometer. ${ }^{1} \mathrm{H}$ shifts are reported in ppm $\left(\delta_{\mathrm{H}}\right)$ downfield from TMS and were determined by reference to the residual solvent peaks $\left(\mathrm{C}_{6} \mathrm{D}_{6}\right.$ : 7.16 ppm, $\mathrm{C}_{7} \mathrm{D}_{8}: 7.09$ ppm, $\mathrm{C}_{6} \mathrm{D}_{12}: 1.38$ ppm, THF- $\mathrm{d}_{8}$ : $3.58 \mathrm{ppm}, \mathrm{D}_{2} \mathrm{O}: 4.75 \mathrm{ppm}$.). Chemical shifts are reported as singlet $(\mathrm{s})$, doublet $(\mathrm{d})$, triplet $(\mathrm{t})$, quartet $(\mathrm{q})$ and multiplet (m). Coupling constants $J$ were reported in $[\mathrm{Hz}] \cdot{ }^{13} \mathrm{C}$ NMR spectra were recorded using the APT or DEPTQ sequence. ${ }^{13} \mathrm{C}$ shifts are reported in ppm $\left(\delta_{\mathrm{C}}\right)$ relative to the solvent resonance $\left(\mathrm{C}_{6} \mathrm{D}_{6}: 128.0 \mathrm{ppm}, \mathrm{C}_{7} \mathrm{D}_{8}: 137.8 \mathrm{ppm}, \mathrm{C}_{6} \mathrm{D}_{12}: 26.4\right.$ ppm, THF- $\mathrm{d}_{8}$ : $25.4 \mathrm{ppm}) .{ }^{31} \mathrm{P}$ NMR chemical shifts are reported in $\mathrm{ppm}\left(\delta_{\mathrm{P}}\right)$ downfield from $\mathrm{H}_{3} \mathrm{PO}_{4}$ and referenced to an external $85 \%$ solution of $\mathrm{H}_{3} \mathrm{PO}_{4}$ in $\mathrm{D}_{2} \mathrm{O}$. For measurements of air sensitive chemical compounds and for spin lattice relaxation time $\left(T_{1}\right)$ experiments, Young-Teflon Capped NMR tubes from Wilmad were used. $T_{1}$ measurements were carried out at $500 \mathrm{MHz}$ using a Bruker DRX 500. Infrared spectra (IR) were measured at room temperature under argon (Glovebox) using a Bruker Alpha spectrometer equipped with a Diamond-ATR IR unit. Data are reported as follows: absorption $\tilde{\nu}\left[\mathrm{cm}^{-1}\right]$, weak (w), medium (m), strong (s). LIFDI-MS (Liquid Injection Field Desorption/Ionization-Mass Spectrometry) was performed using a Waters micromass Q-ToF-2 ${ }^{\mathrm{TM}}$ mass spectrometer equipped with a LIFDI 700 ion source (Linden CMS).

\section{Synthesis of $\left[\mathrm{Ru}\left(\mathrm{H}_{2}\right) \mathrm{H}_{2}(\mathrm{PNP})\right] 4$ and $\left[\mathrm{Ru}\left(\mathrm{H}_{2}\right) \mathrm{H}(\mathrm{PNP})\right] 5$}

In an argon flushed Büchi glass autoclave, $320 \mathrm{mg}(1.0 \mathrm{mmol}$, 1.0 eq.) $\left[\mathrm{Ru}(\right.$ cod $\left.)(2 \text {-methylallyl })_{2}\right] 7$ were added to $400 \mathrm{mg}$ (1.1 mmol, 1.1 eq.) of PNP ligand 8 in $5 \mathrm{~mL}$ pentane. After the autoclave was filled with $\mathrm{H}_{2}$ gas to 5 bar at room temperature, the content was stirred for $48 \mathrm{~h}$ at $55^{\circ} \mathrm{C}$. With the increase in temperature to $55^{\circ} \mathrm{C}$, a $\mathrm{H}_{2}$ pressure of 7 bar was reached. After the reaction mixture was cooled to room temperature, the autoclave was depressurised and flushed twice with argon. After separating the orange mother liquor with a cannula from the yellow solid (mixture 4 and $\mathbf{5}$ ), the product mixture was washed twice with pentane. The pentane was removed via cannula and the product mixture was dried under argon and stored at $-34{ }^{\circ} \mathrm{C}$. Yield: $397.0 \mathrm{mg}$ (product mixture), $0.85 \mathrm{mmol}, 85 \%$.\$

Spectral data of complex 4. ${ }^{1} \mathrm{H}$ NMR $\left(500 \mathrm{MHz}\right.$, toluene- $\left.\mathrm{d}_{8}\right)$ : $\delta_{\mathrm{H}}[\mathrm{ppm}]=4.55$ (weak s, 1H, N-H (H/D-exchange)), 2.91-2.86 $\left(\mathrm{m}, 2 \mathrm{H}, \mathrm{NCH}_{2}\right), 2.54-2.44\left(\mathrm{~m}, 2 \mathrm{H}, \mathrm{NCH}_{2}\right), 2.14-2.12(\mathrm{~m}, 2 \mathrm{H}$, $\left.\mathrm{PCH}_{2}\right), 1.67-1.63\left(\mathrm{~m}, 2 \mathrm{H}, \mathrm{PCH}_{2}\right), 1.41\left(\mathrm{t}, 18 \mathrm{H},{ }^{3} J_{P H}=6.1 \mathrm{~Hz}, \mathrm{PC}-\right.$ $\left.\left(\mathrm{CH}_{3}\right)_{3}\right), 1.36\left(\mathrm{t}, 18 \mathrm{H},{ }^{3} J_{P H}=6.0 \mathrm{~Hz}, \mathrm{PC}\left(\mathrm{CH}_{3}\right)_{3}\right),-8.26(\mathrm{t}, 4 \mathrm{H}$, $\left.{ }^{2} J_{P H}=14.7 \mathrm{~Hz}, \mathrm{Ru}-\mathrm{H}\right) .{ }^{13} \mathrm{C} \mathrm{NMR}\left(75 \mathrm{MHz}\right.$, benzene- $\left.\mathrm{d}_{6}\right): \delta_{\mathrm{C}}$ $[\mathrm{ppm}]=55.7\left(-\mathrm{CH}_{2}-\right), 34.7-32.1\left(\mathrm{PC}\left(\mathrm{CH}_{3}\right)_{3}\right), \quad 30.8-30.5$ $\left(\mathrm{PC}\left(\mathrm{CH}_{3}\right)_{3}\right), 27.4\left(-\mathrm{CH}_{2}-\right) .{ }^{31} \mathrm{P}$ NMR (121 MHz, toluene-d 8$): \delta_{\mathrm{p}}$ $[\mathrm{ppm}]=111.9(\mathrm{~s}) \cdot T_{1}\left(500 \mathrm{MHz}\right.$, toluene-d $\left.\mathrm{d}_{8}\right)=298 \mathrm{~K}(312 \mathrm{~ms})$, $258 \mathrm{~K}(184 \mathrm{~ms}), 238 \mathrm{~K}(148 \mathrm{~ms}), 228 \mathrm{~K}(135 \mathrm{~ms}), 221 \mathrm{~K}$

$\$$ For limited spectral and crystallographic data see ESI. $\dagger$
(132 ms), $208 \mathrm{~K}$ (141 ms), $198 \mathrm{~K}$ (169 ms), $193 \mathrm{~K}$ (191 ms); $\left(T_{1 \min }=132 \mathrm{~ms}, 223 \mathrm{~K}\right)$.

Spectral data of complex 5. ${ }^{1} \mathrm{H}$ NMR (500 MHz, toluene- $\left.\mathrm{d}_{8}\right)$ : $\delta_{\mathrm{H}}[\mathrm{ppm}]=3.46-3.44\left(\mathrm{~m}, 4 \mathrm{H}, \mathrm{NCH}_{2}\right), 1.91-1.85\left(\mathrm{~m}, 4 \mathrm{H}, \mathrm{PCH}_{2}\right)$, $1.30\left(\mathrm{t}, 36 \mathrm{H},{ }^{3} J_{P H}=12.1 \mathrm{~Hz}, \operatorname{PC}\left(\mathrm{CH}_{3}\right)_{3}\right),-12.44\left(\mathrm{t},{ }^{2} J_{P H}=\right.$ $10.6 \mathrm{~Hz}) \cdot{ }^{13} \mathrm{C}$ NMR $\left(75 \mathrm{MHz}\right.$, benzene- $\left.\mathrm{d}_{6}\right): \delta_{\mathrm{C}}[\mathrm{ppm}]=65.6$ $\left(-\mathrm{CH}_{2}-\right), 34.7\left(\mathrm{PC}\left(\mathrm{CH}_{3}\right)_{3}\right), 29.6\left(\mathrm{PC}\left(\mathrm{CH}_{3}\right)_{3}\right), 26.1\left(-\mathrm{CH}_{2}-\right) .{ }^{31} \mathrm{P}$ NMR (121 MHz, toluene- $\left.\mathrm{d}_{8}\right): \delta_{\mathrm{P}}[\mathrm{ppm}]=114.3(\mathrm{~s}) . T_{1}(500 \mathrm{MHz}$, toluene- $\left.\mathrm{d}_{8}\right)=298 \mathrm{~K}(138 \mathrm{~ms}), 258 \mathrm{~K}(97 \mathrm{~ms}), 238 \mathrm{~K}(69 \mathrm{~ms})$, $228 \mathrm{~K}(59 \mathrm{~ms}), 221 \mathrm{~K}(52 \mathrm{~ms}), 208 \mathrm{~K}$ (48 ms), $198 \mathrm{~K}(50 \mathrm{~ms})$, $193 \mathrm{~K}(53 \mathrm{~ms})$; $\left(T_{1 \mathrm{~min}}=48 \mathrm{~ms}, 207 \mathrm{~K}\right)$.

IR (4 and 5): $\tilde{\nu}\left[\mathrm{cm}^{-1}\right]=3291(\mathrm{w}), 2852-2947(\mathrm{~m}), 2034-1995$ (m), 1726 (m), 1470 (m), 1383 (m), $1359(\mathrm{~m}), 1202(\mathrm{w}), 1174$ (m), $1053(\mathrm{w}), 1016(\mathrm{~m}), 923(\mathrm{~m}), 798(\mathrm{~s}), 764(\mathrm{w}), 672(\mathrm{~m}), 644$ (w), $600(\mathrm{~m}), 565(\mathrm{~m}), 471(\mathrm{~s}), 432(\mathrm{~m})$.

\section{Isolation of dihydrogen complex 5}

In an argon flushed Schlenk flask, $25 \mathrm{mg}$ (1.0 eq., $0.054 \mathrm{mmol}$ ) of the mixture of complexes 4 and 5 were dissolved in $2 \mathrm{~mL}$ toluene. The content was stirred for $1 \mathrm{~h}$ at room temperature under a slow stream of argon. The brown-red coloured liquid was removed in vacuo until a green solid 5 remained. The product was stored under an argon atmosphere at $-34{ }^{\circ} \mathrm{C}$. Yield: $18.0 \mathrm{mg}, 0.04 \mathrm{mmol}, 75 \%$.

LIFDI-MS: $m / z 468.0\left(\mathrm{M}^{+}, 91.3\right), 470.1$ (91.3), 466.0 (100), 465.0 (100), 464.0 (56.5), 462.9 (56.5), 462.0 (56.5), 461.0 (21.7), 460.9 (8.7), 460.0 (17.4), 459.0 (8.7).

${ }^{1} \mathrm{H}$ NMR (400 MHz, benzene- $\left.\mathrm{d}_{6}\right): \delta_{\mathrm{H}}[\mathrm{ppm}]=3.46-3.42(\mathrm{~m}$, $\left.4 \mathrm{H}, \mathrm{NCH}_{2}\right), 1.90-1.85\left(\mathrm{~m}, 4 \mathrm{H}, \mathrm{PCH}_{2}\right), 1.22\left(\mathrm{t}, 36 \mathrm{H},{ }^{2} J_{P H}=\right.$ $\left.6.0 \mathrm{~Hz}, \mathrm{PC}\left(\mathrm{CH}_{3}\right)_{3}\right),-12.53\left(\mathrm{t},{ }^{2} J_{P H}=10.7 \mathrm{~Hz}\right) .{ }^{13} \mathrm{C} \mathrm{NMR}$ $\left(75 \mathrm{MHz}\right.$, benzene- $\left.\mathrm{d}_{6}\right): \delta_{\mathrm{C}}[\mathrm{ppm}]=65.6\left(-\mathrm{CH}_{2}-\right)$, 34.7-32.1 $\left(\mathrm{PC}\left(\mathrm{CH}_{3}\right)_{3}\right), 29.6\left(\mathrm{PC}\left(\mathrm{CH}_{3}\right)_{3}\right), 26.1\left(-\mathrm{CH}_{2}-\right) .{ }^{31} \mathrm{P}$ NMR $(121 \mathrm{MHz}$, benzene- $\left.\mathrm{d}_{6}\right): \delta_{\mathrm{P}}[\mathrm{ppm}]=114.3(\mathrm{~s})$.

IR: $\tilde{\nu}\left[\mathrm{cm}^{-1}\right]=3291(\mathrm{w}), 2811-2950(\mathrm{~m}), 2024(\mathrm{~m}), 1471(\mathrm{~m})$, 1383 (w), 1361 (m), 1323 (m), 1204 (m), 1171 (m), 1151 (m), 1093 (w), 1058 (m), 1018 (m), 964 (w), $930(\mathrm{w}), 801$ (m), 733 (m), $692(\mathrm{~m}), 580(\mathrm{~m}), 521(\mathrm{~m}), 471(\mathrm{~s})$.

\section{Generation of dihydrogen complex 4 under $\mathrm{H}_{2}$ atmosphere}

$11 \mathrm{mg}$ (1.0 eq., $0.023 \mathrm{mmol}$ ) of complex 5 was dissolved in $0.1 \mathrm{~mL}$ deuterated toluene and introduced in an argon flushed NMR pressure tube. The NMR tube was pressurised with 2 bar of hydrogen gas. After $60 \mathrm{~h}$ at room temperature, the colour of the content turned from orange into yellow. Full conversion of complex 5 into 4 was detected by NMR.

Spectral data of complex 4. ${ }^{1} \mathrm{H}$ NMR $\left(600 \mathrm{MHz}\right.$, toluene- $\left.\mathrm{d}_{8}\right)$ : $\delta_{\mathrm{H}}[\mathrm{ppm}]=4.55$ (weak, $1 \mathrm{H},(\mathrm{H} / \mathrm{D}$-exchange)), 2.92-2.88 (weak $\left.\mathrm{m}, 2 \mathrm{H}, \mathrm{NCH}_{2}\right), 2.58-2.43\left(\mathrm{~m}, 2 \mathrm{H}, \mathrm{NCH}_{2}\right), 1.94-1.88(\mathrm{~m}, 2 \mathrm{H}$, $\left.\mathrm{PCH}_{2}\right), 1.67-1.63\left(\mathrm{~m}, 2 \mathrm{H}, \mathrm{PCH}_{2}\right), 1.41\left(\mathrm{t}, 18 \mathrm{H},{ }^{3} J_{P H}=5.9 \mathrm{~Hz}, \mathrm{PC}-\right.$ $\left.\left(\mathrm{CH}_{3}\right)_{3}\right), 1.30\left(\mathrm{t}, 18 \mathrm{H},{ }^{3} J_{P H}=5.9 \mathrm{~Hz}, \mathrm{PC}\left(\mathrm{CH}_{3}\right)_{3}\right),-8.25(\mathrm{t}, 4 \mathrm{H}$, $\left.{ }^{2} J_{P H}=14.5 \mathrm{~Hz}, \mathrm{Ru}-\mathrm{H}\right) .{ }^{13} \mathrm{C} \mathrm{NMR}\left(75 \mathrm{MHz}\right.$, toluene-d $\left.\mathrm{d}_{8}\right): \delta_{\mathrm{C}}[\mathrm{ppm}]$ $\left.=55.7\left(-\mathrm{CH}_{2}-\right), \mathrm{PC}\left(\mathrm{CH}_{3}\right)_{3}\right), 30.8-30.4\left(\mathrm{PC}\left(\mathrm{CH}_{3}\right)_{3}\right), 27.4\left(-\mathrm{CH}_{2}{ }^{-}\right)$. ${ }^{31} \mathrm{P}$ NMR (121 MHz, toluene-d $\left.{ }_{8}\right): \delta_{\mathrm{p}}[\mathrm{ppm}]=111.9(\mathrm{~s})$; Note to ${ }^{13} \mathrm{C}-\mathrm{NMR}$ : The quaternary carbons between 34.7 and 32.1 (see synthesis of complexes $\mathbf{4}$ and 5) were not detected due to low solubility of complex 5 in $0.1 \mathrm{~mL}$ deuterated toluene, pointing 
out that the NMR pressure tube has an inner measurable volume of $0.1 \mathrm{~mL}$.

\section{Synthesis of Me-PNP ligand 9}

Synthesis of $\mathrm{N}$-methyl bis(2-chloroethyl)amine hydrochloride. $17.0 \mathrm{~g}$ (0.096 mol) bis(2-chloroethyl)amine hydrochloride and $10.0 \mathrm{~g}(0.2 \mathrm{~mol})$ formic acid were added to $20 \mathrm{~mL}$ of a $37 \%$ formaldehyde solution in a $500 \mathrm{~mL}$ round bottom flask equipped with a reflux condenser. After the reaction mixture was refluxed for $3 \mathrm{~h}$ at $100{ }^{\circ} \mathrm{C}$ and cooled to room temperature, the solvent was removed in vacuo until a yellowwhite solid was obtained. For further purification, the solid was dissolved in $100 \mathrm{~mL}$ THF. After removing the solvent, the product was obtained as a white solid which was directly used for the synthesis of PNP ligand 9 (18.41 g, 99\%).

${ }^{1} \mathrm{H}$ NMR $\left(300 \mathrm{MHz}, \mathrm{D}_{2} \mathrm{O}\right): \delta_{\mathrm{H}}=2.96\left(\mathrm{~s}, 3 \mathrm{H}, \mathrm{NCH}_{3}\right), 3.63(\mathrm{bs}$, $\left.4 \mathrm{H},-\mathrm{CH}_{2} \mathrm{CH}_{2}-\right), 3.93\left(\mathrm{t}, 4 \mathrm{H},{ }^{2} J_{\mathrm{HH}}=5.8 \mathrm{~Hz},-\mathrm{CH}_{2} \mathrm{CH}_{2}-\right)$.

\section{Synthesis of Me-PNP 9}

In a flame dried and argon flushed $500 \mathrm{~mL}$ Schlenk flask, $8.75 \mathrm{~mL}$ (47.15 mmol, $2.3 \mathrm{eq}$.) of di-tert-butyl phosphine was dissolved in $60 \mathrm{~mL}$ diethyl ether. After cooling to $-78{ }^{\circ} \mathrm{C}$, $18 \mathrm{~mL}$ of a $2 \mathrm{M}$ in hexane butyl lithium solution was added dropwise to the content under constant stirring. The reaction mixture was allowed to reach room temperature and the Schlenk flask was equipped with a reflux condenser and heated for $4 \mathrm{~h}$ at $50^{\circ} \mathrm{C}$ under an argon atmosphere until a yellow solid of di-tert-butyl phosphine lithium was obtained. In a flame dried and argon flushed $250 \mathrm{~mL}$ Schlenk flask $3.9 \mathrm{~g}$ (20.5 mmol, 1.0 eq.) $\mathrm{N}$-methyl bis(2-chloroethyl)amine hydrochloride was dissolved in $50 \mathrm{~mL}$ diethyl ether and cooled to $-78{ }^{\circ} \mathrm{C}$. Under constant stirring, $8.16 \mathrm{~mL}$ of a $2 \mathrm{M}$ in hexane butyl lithium solution was added dropwise within $30 \mathrm{~min}$ to the content. After allowing the reaction mixture to reach room temperature, the content was stirred for $2 \mathrm{~h}$ and transferred slowly via a transfer cannula to the precooled di-tert-butyl phosphine lithium in the $500 \mathrm{~mL}$ Schlenk flask at $-78^{\circ} \mathrm{C}$. The unified reaction mixture was allowed to reach room temperature and then refluxed overnight at $60{ }^{\circ} \mathrm{C}$ under an argon atmosphere. The reaction mixture was allowed to reach room temperature, the solution was separated in a flame dried and argon flushed Schlenk tube from the solid lithium chloride via centrifuge. The ether was removed in vacuo and replaced with $50 \mathrm{~mL}$ pentane. The content was extracted 3 times with degassed water and dried over magnesium sulphate. After filtration, the solvent was removed in vacuo to obtain a yellow oil (5.3 g, $14.15 \mathrm{mmol}$, 69\% yield, purity 67\%). Major impurities stemmed from the excess of di-tert-butyl phosphine. Ligand 9 was used without further purification. For analytical data, the product was dissolved in a solution of pentane and triethylamine $(1: 1)$. After stirring the content for $30 \mathrm{~min}$, the solvent mixture was removed in vacuo to obtain a clearer oil with a purity of $80 \%$ or higher.

${ }^{1} \mathrm{H}$ NMR (300 MHz, benzene- $\left.\mathrm{d}_{6}\right): \delta_{\mathrm{H}}=2.91-2.84(\mathrm{~m}, 4 \mathrm{H}$, $\left.-\mathrm{CH}_{2} \mathrm{CH}_{2}-\right), 2.40\left(\mathrm{~s}, 3 \mathrm{H},-\mathrm{CH}_{3}\right), 1.81-1.74\left(\mathrm{~m}, 4 \mathrm{H},-\mathrm{CH}_{2} \mathrm{CH}_{2}-\right)$, $1.23(18 \mathrm{H}, \mathrm{s}), 1.20(18 \mathrm{H}, \mathrm{s}) .{ }^{13} \mathrm{C}$ NMR (75 MHz, benzene- $\left.\mathrm{d}_{6}\right)$ :
$\delta_{\mathrm{C}}=58.9-58.4\left(\mathrm{CH}_{2}\right), 41.8\left(\mathrm{NCH}_{3}\right), 31.2-30.6\left(\mathrm{P}\left(\mathrm{C}\left(\mathrm{CH}_{3}\right)_{3}\right)\right)$, 29.7-29.5 $\left(\mathrm{P}\left(\mathrm{C}\left(\mathrm{CH}_{3}\right)_{3}\right)\right), 20.0-19.7\left(\mathrm{CH}_{2}\right),{ }^{31} \mathrm{P}$ NMR $(121 \mathrm{MHz}$, benzene- $\left.\mathrm{d}_{6}\right): \delta_{\mathrm{P}}=24.7(\mathrm{~s})$.

\section{Synthesis of $\left[\mathrm{Ru}\left(\mathrm{H}_{2}\right) \mathrm{H}_{2}(\mathrm{Me}-\mathrm{PNP})\right] 6$}

In an argon flushed Büchi glass autoclave, $240 \mathrm{mg}(0.75 \mathrm{mmol}$, 1.0 eq.) of $\left[\mathrm{Ru}(\operatorname{cod})(2 \text {-methylallyl })_{2}\right] 7$ were added to $413 \mathrm{mg}$ (regarding the purity grade of $67 \%, 1.1 \mathrm{mmol}, 1.45$ eq.) of ligand 9 in $5 \mathrm{~mL}$ pentane. After the autoclave was filled with $\mathrm{H}_{2}$ gas to 5.5 bar at room temperature, the content was stirred for $48 \mathrm{~h}$ at $60{ }^{\circ} \mathrm{C}$. With the increase in temperature to $60^{\circ} \mathrm{C}$, a $\mathrm{H}_{2}$ pressure of 6.5 bar was reached. After the reaction mixture was cooled to room temperature, the autoclave was depressurised, flushed twice with argon and stored under an argon atmosphere at $-34{ }^{\circ} \mathrm{C}$ for $12 \mathrm{~h}$. The dark red mother liquor was separated with a cannula from the grey solid and the product was washed twice with precooled pentane. The pentane was removed via a cannula and the product was dried under argon and stored at $-34{ }^{\circ} \mathrm{C}$. Yield: $242 \mathrm{mg}$, $0.50 \mathrm{mmol}, 67 \%$.

LIFDI-MS: $m / z 484.1\left(\mathrm{M}^{+}, 22.2\right), 483.1$ (66.7), 483.0 (33.3), 482.0 (44.4), 481.1 (100), 480.0 (77.8), 479.1 (55.5), 479.0 (44.4), 478.1 (33.3), 478.1 (44.4), 478.0 (55.6), 477.1 (22.2), 477.0 (11.1), 476.1 (22.2), 476.0 (11.1), 475.1 (22.2), 475.0 (11.1).

${ }^{1} \mathrm{H}$ NMR (300 MHz, toluene- $\left.\mathrm{d}_{8}\right): \delta_{\mathrm{H}} \mathrm{ppm}=2.52-2.43(\mathrm{~m}, 2 \mathrm{H}$, $\left.\mathrm{NCH}_{2}\right), 2.4\left(\mathrm{~s}, 3 \mathrm{H},-\mathrm{CH}_{3}\right), 2.28-2.18\left(\mathrm{~m}, 2 \mathrm{H}, \mathrm{NCH}_{2}\right), 1.81-1.74$ $\left(\mathrm{m}, 2 \mathrm{H}, \mathrm{PCH}_{2}\right), 1.64-1.58\left(\mathrm{~m}, 2 \mathrm{H}, \mathrm{PCH}_{2}\right), 1.44\left(\mathrm{t}, 18 \mathrm{H},{ }^{3} J_{P H}=\right.$ $6.1 \mathrm{~Hz}), 1.31\left(\mathrm{t}, 18 \mathrm{H},{ }^{3} J_{P H}=6.1 \mathrm{~Hz}\right),-8.68\left(\mathrm{t}, 4 \mathrm{H},{ }^{2} J_{P H}=\right.$ $13.8 \mathrm{~Hz}) .{ }^{13} \mathrm{C}$ NMR: $\left(75 \mathrm{MHz}\right.$, toluene-d $\left.{ }_{8}\right): \delta_{\mathrm{C}}[\mathrm{ppm}]=66.3-66.2$ $\left(\mathrm{CH}_{2}\right), \quad 53.3\left(\mathrm{CH}_{3}\right), \quad 34.1 \quad\left(\mathrm{P}\left(\mathrm{C}\left(\mathrm{CH}_{3}\right)_{3}\right)\right), 31.9 \quad\left(\mathrm{P}\left(\mathrm{C}\left(\mathrm{CH}_{3}\right)_{3}\right)\right)$, 30.9-30.7 $\left.\mathrm{P}\left(\mathrm{C}\left(\mathrm{CH}_{3}\right)_{3}\right)\right), 25.6\left(\mathrm{CH}_{2}\right) .{ }^{31} \mathrm{P}$ NMR: $(121 \mathrm{MHz}$, toluene- $\left.\mathrm{d}_{8}\right): \delta_{\mathrm{P}}[\mathrm{ppm}]=108.7(\mathrm{~s})$.

$T_{1}\left(500 \mathrm{MHz}\right.$, toluene- $\left.\mathrm{d}_{8}\right)=299 \mathrm{~K}(198 \mathrm{~ms}), 278 \mathrm{~K}(130 \mathrm{~ms})$, $268 \mathrm{~K}(106 \mathrm{~ms}), 258 \mathrm{~K}$ ( $86 \mathrm{~ms}), 248 \mathrm{~K}$ (71 ms), $238 \mathrm{~K}$ (60 ms), $228 \mathrm{~K}(53 \mathrm{~ms}), 218 \mathrm{~K}(54 \mathrm{~ms}), 208 \mathrm{~K}(62 \mathrm{~ms}),\left(T_{1 \mathrm{~min}}=54 \mathrm{~ms}\right.$, $224 \mathrm{~K})$.

IR: $\tilde{\nu}\left[\mathrm{cm}^{-1}\right]=2985(\mathrm{w}), 2937-2856(\mathrm{~m}), 1972-1923(\mathrm{~m}), 1776$ (m), 1475-1446 (m), 1415 (w), 1383 (m), 1362 (w), 1350 (m), 1317 (w), 1235 (w), 1207 (m), 1172 (m), 1039 (m), 1018 (m), 930 (w), $913(\mathrm{w}), 878(\mathrm{~m}), 806(\mathrm{~s}), 737(\mathrm{~m}), 670(\mathrm{~m}), 652(\mathrm{~m}), 597$ (m), $564(\mathrm{~m}), 527(\mathrm{w})$.

\section{Synthesis of complex $\left[\mathrm{RuH}_{2}(\mathrm{HBPin})(\mathrm{Me}-\mathrm{PNP})\right] 10$}

In an argon flushed Schlenk flask equipped with a bubbler, $100 \mathrm{mg}$ (1.0 eq., $0.20 \mathrm{mmol}$ ) of complex 6 were dissolved in $6 \mathrm{~mL}$ toluene. $33 \mu \mathrm{L}$ (1.1 eq., $0.22 \mathrm{mmol})$ of pinacol borane were added to the content and stirred for $2 \mathrm{~h}$ at room temperature. The green coloured solvent was removed in vacuo until a green solid (10) remained. The product was stored under an argon atmosphere at $-34{ }^{\circ} \mathrm{C}$. Yield: $111.0 \mathrm{mg}, 0.176 \mathrm{mmol}$, $88 \%$.

LIFDI-MS: $m / z 610.0\left(\mathrm{M}^{+}, 0.6 \%\right), 609.0$ (0.6), 608.0 (0.6), 607.4 (1.3), 607.3 (1.3), $606.5(0.6), 606.4$ (0.6), 606.3 (1.3), 605.3 (1.9), 604.4 (1.3), 603.1 (0.6), 602.2 (0.6), 601.3 (0.6), 484.8 (1.3), 482.1 (50.0), 481.9 (19.5), 481.1 (27.0), 480.2 (26.5), 480.1 (100), 480.0 (49.7), 479.1 (66.0), 479.0 (22.6), 478.1 (69.8), 
478.0 (13.8), 477.1 (46.5), 477.0 (21.4), 476.0 (28.9), 476.0 (6.3), 475.1 (18.9), 475.0 (3.8).

${ }^{1} \mathrm{H}$ NMR $\left(300 \mathrm{MHz}, \mathrm{C}_{6} \mathrm{D}_{12}\right): \delta_{\mathrm{H}}[\mathrm{ppm}]=2.61-2.54(\mathrm{~m}, 2 \mathrm{H}$, $\mathrm{NCH}_{2}$ ), 2.59 (s, 3H, $\mathrm{CH}_{3}$ ), 2.44-2.38 (m, 4H, $\left.\mathrm{NCH}_{2}\right), 2.10-1.95$ $\left(\mathrm{m}, 2 \mathrm{H}, \mathrm{PCH}_{2}\right), 1.84-1.72\left(\mathrm{~m}, 2 \mathrm{H}, \mathrm{PCH}_{2}\right), 1.49\left(\mathrm{t}, 18 \mathrm{H},{ }^{3} J_{P H}=\right.$ $5.8 \mathrm{~Hz},), 1.41$ (t, 18H, ${ }^{3} J_{P H}=6.1 \mathrm{~Hz}$ ), $1.11(12 \mathrm{H}, \mathrm{s}, \mathrm{Pin}),-5.64$ (bs, 1H, Ru-H-B), -9.02 (bs, 1H, Ru-H-B), -18.85 (bs, 1H, RuH). $\left.{ }^{13} \mathrm{C} \mathrm{NMR} \mathrm{(75} \mathrm{MHz,} \mathrm{C}_{6} \mathrm{D}_{12}\right): \delta_{\mathrm{C}}[\mathrm{ppm}]=80.1\left(\mathrm{Pin}, \mathrm{C}_{\mathrm{q}}\right), 66.2$ $\left(\mathrm{CH}_{2}\right)$, 34.5-34.3 $\left(\mathrm{P}\left(\mathrm{C}\left(\mathrm{CH}_{3}\right)_{3}\right)\right)$, 32.5-32.2 $\left(\mathrm{P}\left(\mathrm{C}\left(\mathrm{CH}_{3}\right)_{3}\right)\right) 29.2(\mathrm{P}(\mathrm{C}-$ $\left.\left.\left(\mathrm{CH}_{3}\right)_{3}\right)\right), 25.5\left(\mathrm{CH}_{2}\right), 23.8\left(\mathrm{Pin}-\mathrm{CH}_{3}\right) .{ }^{31} \mathrm{P} \mathrm{NMR}:(121 \mathrm{MHz}$, $\left.\mathrm{C}_{6} \mathrm{D}_{12}\right): \delta_{\mathrm{P}}[\mathrm{ppm}]=92.1(\mathrm{~s}),{ }^{11} \mathrm{~B}-\mathrm{NMR}\left(160 \mathrm{MHz}, \mathrm{C}_{6} \mathrm{D}_{12}\right)$ : $37.8(\mathrm{~s})$.

IR: $\tilde{\nu}\left[\mathrm{cm}^{-1}\right]=2959(\mathrm{~m}), 2897-2867(\mathrm{~m}), 2032(\mathrm{w}), 1964-1924$ (w), 1746-1688 (w), 1482 (m), 1461 (m), 1384 (m), 1360 (m), 1310 (w), 1268 (w), 1218 (w), 1178 (m), 1160 (m), 1040 (s), 933 (w), $877(\mathrm{~m}), 804(\mathrm{~s}), 739(\mathrm{~m}), 570(\mathrm{~m})$.

\section{Synthesis of $(\sigma-\mathrm{B}-\mathrm{H})$-complex $\left[\mathrm{RuH}_{2}\left(\mathrm{BH}_{3}\right)(\mathrm{Me}-\mathrm{PNP})\right] 11$}

Route a. In an argon flushed Schlenk flask equipped with a bubbler, $70 \mathrm{mg}$ (1.0 eq., $0.14 \mathrm{mmol})$ of complex 6 were dissolved in $5 \mathrm{~mL}$ toluene. $0.36 \mathrm{~mL}$ (2.6 eq., $0.36 \mathrm{mmol}$ ) THF borane complex of a $1 \mathrm{M}$ THF solution were added to the content and stirred for $2 \mathrm{~h}$ at room temperature. The solvent was removed in vacuo until a yellow solid $\mathbf{1 1}$ remained. The product was stored under an argon atmosphere at $-34{ }^{\circ} \mathrm{C}$. Yield: $70.0 \mathrm{mg}, 0.13 \mathrm{mmol}$, 92\%.

Route b. In an argon flushed Schlenk flask equipped with a bubbler, $50 \mathrm{mg}$ (1.0 eq., $0.1 \mathrm{mmol})$ of complex 6 were dissolved in a mixture of $4 \mathrm{~mL}$ toluene and $2 \mathrm{~mL}$ pentane. $29 \mathrm{mg}$ (5.0 eq., $0.5 \mathrm{mmol}$ ) of $\mathrm{H}_{3} \mathrm{BNHMe}_{2}$ were added to the content and stirred for $2 \mathrm{~h}$ at room temperature. The solvent was removed in vacuo until a yellow solid $\mathbf{1 1}$ remained. The product was stored under an argon atmosphere at $-34{ }^{\circ} \mathrm{C}$. Yield: $44.0 \mathrm{mg}, 0.082 \mathrm{mmol}, 82 \%$.

\section{Preparation of $\left[\mathrm{RuH}_{2}\left(\mathrm{BH}_{3}\right)(\mathrm{Me}-\mathrm{PNP})\right] 11$ for single crystal analysis}

In a headspace vial, $20 \mathrm{mg}$ of complex $\mathbf{1 1}$ were dissolved in $3 \mathrm{~mL}$ pentane and kept overnight at room temperature under an argon atmosphere. After the solvent was evaporated under the argon atmosphere, the yellow crystals were stored in $3 \mathrm{~mL}$ pentane at $-34^{\circ} \mathrm{C}$.

Elementary analysis calculated for $\mathrm{C}_{21} \mathrm{H}_{52} \mathrm{BNP}_{2} \mathrm{Ru}$ (493.47) $\mathrm{C} 51.22, \mathrm{H} 10.64, \mathrm{~B} 2.20, \mathrm{~N} 2.84, \mathrm{P} 12.58, \mathrm{Ru} 20.52$; found: $\mathrm{C} 50.88, \mathrm{H} 9.71, \mathrm{~B} 2.20, \mathrm{~N} 2.50, \mathrm{P} 12.58, \mathrm{Ru} 20.52$. Atom ratio found by $\mathrm{CHN}$ : $\mathrm{C}_{20.9} \mathrm{H}_{47.5} \mathrm{~N}_{0.9} \mathrm{~B}_{1.0} \mathrm{P}_{2.0} \mathrm{Ru}_{1.0}$.

LIFDI-MS: $m / z$ 496.2 ( $\left.\mathrm{M}^{+}, 7.1\right), 496.1$ (14.3), 495.2 (42.9), 495.0 (7.1), 494.5 (7.1), 494.1 (57.1), 493.2 (14.2), 493.1 (100), 493.0 (35.7), 492.1 (92.9), 492.0 (28.6), 491.1 (35.7), 491.0 (50.0), 490.1 (42.9), 490.0 (7.3), 489.2 (14.3), 488.1 (7.1), 487.1 (28.6), 487.0 (14.3).

${ }^{1} \mathrm{H}$ NMR: (400 MHz, toluene- $\left.\mathrm{d}_{8}\right): \delta_{\mathrm{H}}[\mathrm{ppm}]=5.42(\mathrm{bs}, 2 \mathrm{H}$, $\left.\mathrm{BH}_{2}\right), 2.19\left(\mathrm{~s}, 3 \mathrm{H}, \mathrm{CH}_{3}\right), 2.10-2.02\left(\mathrm{~m}, 2 \mathrm{H}, \mathrm{NCH}_{2}\right), 2.01-1.93$ $\left(\mathrm{m}, 2 \mathrm{H}, \mathrm{NCH}_{2}\right), 1.68-1.61\left(\mathrm{~m}, 2 \mathrm{H}, \mathrm{PCH}_{2}\right), 1.52\left(\mathrm{bt}, 18 \mathrm{H},{ }^{3} J_{P H}=\right.$ $4.9 \mathrm{~Hz}), 1.48-1.45\left(\mathrm{~m}\right.$, overlapped, $\left.2 \mathrm{H}, \mathrm{PCH}_{2}\right), 1.40(\mathrm{t}, 18 \mathrm{H}$, $\left.{ }^{3} J_{P H}=6.1 \mathrm{~Hz}\right),-5.69(\mathrm{bs}, 1 \mathrm{H}, \sigma-\mathrm{Ru}-\mathrm{H}-\mathrm{B}),-17.85\left(\mathrm{td}, 1 \mathrm{H},{ }^{2} J_{P H}=\right.$ $\left.19.22 \mathrm{~Hz},{ }^{2} J_{B H}=3.52 \mathrm{~Hz}, \mathrm{Ru}-\mathrm{H}\right),-19.76$ (bs, $\left.1 \mathrm{H}, \mathrm{Ru}-\mathrm{H}-\mathrm{B}\right) .{ }^{13} \mathrm{C}$ NMR: (75 MHz, toluene-d $\left.\mathrm{d}_{8}\right): \delta_{\mathrm{C}}[\mathrm{ppm}]=67.0\left(\mathrm{CH}_{2}\right), 51.4\left(\mathrm{CH}_{3}\right)$, $35.1\left(\mathrm{P}\left(\mathrm{C}\left(\mathrm{CH}_{3}\right)_{3}\right)\right), 33.9\left(\mathrm{P}\left(\mathrm{C}\left(\mathrm{CH}_{3}\right)_{3}\right)\right), 30.2\left(\mathrm{P}\left(\mathrm{C}\left(\mathrm{CH}_{3}\right)_{3}\right)\right), 24.13\left(\mathrm{CH}_{2}\right)$. ${ }^{31}$ P NMR: (121 MHz, toluene- $\left.\mathrm{d}_{8}\right): \delta_{\mathrm{P}}[\mathrm{ppm}]=84.9(\mathrm{~s}) .{ }^{11} \mathrm{~B}$ NMR (160 MHz, toluene- $\left.\mathrm{d}_{8}\right): 19.2(\mathrm{~s})$.

IR: $\tilde{\nu}\left[\mathrm{cm}^{-1}\right]=2966-2861(\mathrm{~m}), 2394(\mathrm{~m}), 2330(\mathrm{~m}), 2020(\mathrm{~m})$, 1815 (w), 1693 (m), 1472 (m), 1441 (m), $1384(\mathrm{w}), 1363(\mathrm{w})$, 1326 (w), 1257 (m), 1097 (w), 1039-1033 (m), 927 (w), 907 (w), $870(\mathrm{~m}), 805(\mathrm{~m}), 740(\mathrm{~m}), 672(\mathrm{~m}), 600(\mathrm{~m}), 573(\mathrm{~m}), 529(\mathrm{w})$, $478(\mathrm{~m})$.

\section{Acknowledgements}

We acknowledge the Ministerium für Innovation, Wissenschaft und Forschung NRW (MIWF-NRW) for financial support within the Energy Research Program for the Scientist Returnee Award for M. H. G. Prechtl (NRW-Rückkehrerprogramm). For access to LIFDI-MS analysis, we gratefully acknowledge Prof. Dr T. Braun (Humboldt-University of Berlin, Germany). J-H. Choi wants to thank C. Hegemann, M. Keßler and S. Sahler for helpful discussion.

\section{Notes and references}

1 J. Zhang, G. Leitus, Y. Ben-David and D. Milstein, Angew. Chem., Int. Ed., 2006, 45, 1113-1115.

2 C. Gunanathan, Y. Ben-David and D. Milstein, Science, 2007, 317, 790-792.

3 M. H. G. Prechtl, M. Hölscher, Y. Ben-David, N. Theyssen, R. Loschen, D. Milstein and W. Leitner, Angew. Chem., Int. Ed., 2007, 46, 2269-2272.

4 G. Alcaraz, L. Vendier, E. Clot and S. Sabo-Etienne, Angew. Chem., Int. Ed., 2010, 49, 918-920.

5 G. J. Kubas and R. R. Ryan, Polyhedron, 1986, 5, 473485.

6 G. J. Kubas, R. R. Ryan, B. I. Swanson, P. J. Vergamini and H. J. Wasserman, J. Am. Chem. Soc., 1984, 106, 451-452.

7 G. J. Kubas, Chem. Rev., 2007, 107, 4152-4205.

8 R. H. Crabtree and M. Lavin, J. Am. Chem. Soc., 1985, 23, 1661-1662.

9 D. G. Hamilton and R. H. Crabtree, J. Am. Chem. Soc., 1988, 110, 4126-4133.

10 B. Chaudret and R. Poilblanc, Organometallics, 1985, 4, 1722-1726.

11 Y. Guari, A. Castellanos, S. Sabo-Etienne and B. Chaudret, J. Mol. Catal. A: Chem., 2004, 212, 77-82.

12 G. J. Kubas, J. Organomet. Chem., 2001, 635, 37-68.

13 G. Alcaraz and S. Sabo-Etienne, Angew. Chem., Int. Ed., 2010, 49, 7170-7179.

14 G. Alcaraz, A. B. Chaplin, C. J. Stevens, E. Clot, L. Vendier, A. S. Weller and S. Sabo-Etienne, Organometallics, 2010, 29, 5591-5595. 
15 T. J. Hebden, M. C. Denney, V. Pons, P. M. B. Piccoli, T. F. Koetzle, A. J. Schultz, W. Kaminsky, K. I. Goldberg and D. M. Heinekey, J. Am. Chem. Soc., 2008, 130, 1081210820.

16 M. Hölscher, M. H. G. Prechtl and W. Leitner, Chem.-Eur. J., 2007, 13, 6636-6643.

17 C. Gunanathan, M. Hölscher, F. Pan and W. Leitner, J. Am. Chem. Soc., 2012, 134, 14349-14352.

18 M. H. G. Prechtl, Y. Ben-David, D. Giunta, S. Busch, Y. Taniguchi, W. Wisniewski, H. Goerls, R. J. Mynott, N. Theyssen, D. Milstein and W. Leitner, Chem.-Eur. J., 2007, 13, 1539-1546.

19 B. Askevold, J. T. Nieto, S. Tussupbayev, M. Diefenbach, E. Herdtweck, M. C. Holthausen and S. Schneider, Nat. Chem., 2011, 3, 532-537.

20 P. G. Jessop and R. H. Morris, Coord. Chem. Rev., 1992, 121, 155-284.

21 T. Arliguie, B. Chaudret, R. H. Morris and A. Sella, Inorg. Chem., 1988, 27, 598-599.

22 J. Zhang, M. Gandelman, L. J. W. Shimon, H. Rozenberg and D. Milstein, Organometallics, 2004, 23, 4026-4033.
23 J. Zhang, G. Leitus, Y. Ben-David and D. Milstein, J. Am. Chem. Soc., 2005, 127, 12429-12429.

24 J. Zhang, E. Balaraman, G. Leitus and D. Milstein, Organometallics, 2011, 30, 5716-5724.

25 D. A. Addy, J. I. Bates, M. J. Kelly, I. M. Riddlestone and S. Aldridge, Organometallics, 2013, 32, 1583-1586.

26 T. Ohkuma, M. Koizumi, K. Muniz, G. Hilt, C. Kabuto and R. Noyori, J. Am. Chem. Soc., 2002, 124, 6508-6509.

27 M. G. Crestani, M. Muñoz-Hernández, A. Arévalo, A. Acosta-Ramírez and J. J. García, J. Am. Chem. Soc., 2005, 127, 18066-18073.

28 R. Langer, M. A. Iron, L. Konstantinovski, Y. Diskin-Posner, G. Leitus, Y. Ben-David and D. Milstein, Chem.-Eur. J., 2012, 18, 7196-7209.

29 B. Pan, S. Pierre, M. W. Bezpalko, J. W. Napoline, B. M. Foxman and C. M. Thomas, Organometallics, 2013, 32, 704-710.

30 D. Giunta, M. Hölscher, C. W. Lehmann, R. Mynott, C. Wirtz and W. Leitner, Adv. Synth. Catal., 2003, 345, 1139-1145.

31 V. Rodriguez, I. Atheaux, B. Donnadieu, S. Sabo-Etienne and B. Chaudret, Organometallics, 2000, 19, 2916-2926. 